\title{
POLA HUBUNGAN KERJA NELAYAN PERAIRAN UMUM DARATAN DI KABUPATEN OGAN KOMERING ILIR, PROVINSI SUMATERA SELATAN \\ (Studi Kasus di Desa Berkat, Kecamatan Sirah Pulau Padang) \\ Work Pattern of Inland Water Fishers in Ogan Komering Ilir District, South Sumatra Province (Case Study on Berkat Village, Sirah Pulau Padang Sub District)
}

\author{
Maulana Firdaus dan Nensyana Shafitri \\ Balai Besar Penelitian Sosial Ekonomi Kelautan dan Perikanan \\ JI. KS. Tubun Petamburan VI Jakarta 10260 \\ Telp. (021) 53650162, Fax. (021)53650159 \\ Email:mr firda@hotmail.com
}

Diterima 25 September 2013 - Disetujui 29 Nopember 2013

\begin{abstract}
ABSTRAK
Dalam kehidupan masyarakat perikanan terdapat berbagai macam hubungan kerja yang terjadi antara pemilik dan pekerja. Beberapa wilayah di Indonesia, pola hubungan kerja ini memiliki karakteristik tersendiri, seperti punggawa-sawi, juragan-pandega, tauke-nelayan. Adanya hubungan kerja dalam masyarakat nelayan tidak terlepas dari kondisi sumberdaya ikan di perairan yang bersifat open access. Sejauh ini informasi terkait pola hubungan kerja nelayan di perairan umum daratan belum banyak diungkap. Penelitian ini bertujuan untuk mengkaji pola hubungan kerja pada nelayan di sungai dan rawa banjiran. Penelitian ini dilakukan di Desa Berkat, Kecamatan Sirah Pulau Padang, Kabupaten Ogan Komering Ilir. Dilaksanakan pada bulan Mei dan Agustus 2012. Data primer dan sekunder digunakan dalam penelitian ini. Data primer diperoleh dari hasil wawancara mendalam dengan informan kunci secara individual dengan menggunakan daftar pertanyaan terstruktur. Informan ditentukan secara purposive sampling. Data sekunder diperoleh melalui studi pustaka, serta informasi dari instansiinstansi terkait baik pemerintah dan swasta.
\end{abstract}

Kata Kunci: pola, hubungan kerja, nelayan, perairan umum daratan

\begin{abstract}
In the fishing communities there were varoius working relationship between owners and workers. In some parts of Indonesia, the pattern of employment has its own characteristics, such as retainer-mustard, skipper-owner, employer-labor relations in the presence of fishers community were inseparable with fish resources condition in open access waters. So far information related to fisher's employment relations pattern in inland waters has not been revealed. This study aimed to examine fishers employment pattern in inland waters. The research was conducted in Berkat Village, Sirah Pulau Padang Sub District, Ogan Komering Ilir District. This research was conducted in May and August 2012. Primary and secondary data were used in this study. Primary data obtained from interviews with key informants individually using a structured questionnaire. Informants are determined by purposive sampling. Secondary data obtained through the study of literature, as well as information from relevant agencies both government and private.
\end{abstract}

Keywords: patterns, work relationships, fishers, inland water 


\section{PENDAHULUAN}

Dalam kehidupan masyarakatpesisirterdapat berbagai macam hubungan kerja yang terjadi antara pemilik dan pekerja. Di beberapa wilayah pesisir di Indonesia, pola hubungan kerja ini memiliki karakteristik tersendiri, seperti di Sulawesi Selatan dikenal hubungan antara punggawa-sawi (Salman dan Taryoto, 1992), di pantai utara Jawa dikenal hubungan antara juragan-pandega (Mubyarto, 1984), sedangkan di Sumatera Utara terdapat hubungan antara tauke-nelayan (Mintoro et al., 1993). Adanya hubungan kerja dalam masyarakat nelayan tidak terlepas dari kondisi sumberdaya ikan di laut yang bersifat open access. Kondisi tersebut tidak hanya terjadi pada masyarakat nelayan laut namun juga terjadi pada masyarakat nelayan di perairan umum daratan (sungai, rawa banjiran, waduk dan danau), contohnya seperti di Waduk Jatiluhur (Jawa Barat) dikenal dengan istilah bandar - nelayan (Koeshendrajana et al., 2011).

Provinsi Sumatera Selatan merupakan salah satu daerah di Indonesia yang memiliki wilayah perairan umum daratan (PUD) yang luas dan merupakan penghasil ikan air tawar utama bagi kebutuhan masyararakat. Tipe perairan umum daratan terluas terdapat di Kabupaten Ogan Komering llir (Kabupaten OKI), sekitar 65 persen wilayahnya berupa rawa, payau, lebak dan sungai (Nasution, 2008). Terkait dengan pemanfaatan sumberdaya ikan di PUD khususnya pada tipe sungai dan rawa banjiran yang ada di Kabupaten OKI tidak semuanya bersifat open acces, karena ada beberapa wilayah badan air yang hanya dapat dimanfaatkan/diambil ikannya oleh pihak tertentu saja. Wilayah badan air tersebut biasanya merupakan wilayah yang dilelang oleh pemerintah setempat. Pemberian hak usaha penangkapan oleh pemerintah dilakukan memelalui sistem pelelangan yang dikenal dengan istilah lelang lebak lebung. Hak usaha penangkapan ikan diberikan kepada pihak yang telah memenangkan lelang atau dikenal dengan istilah pengemin.

Menurut Nasution (1990) dalam Nasution (2008) mengatakan, sistem lelang diberlakukan oleh pemerintah setempat dengan pertimbangan untuk mencegah terjadinya perebutan sumberdaya di antara nelayan dalam hal menangkap ikan dan memperoleh Pendapatan Asli Daerah (PAD), namun secara tidak langsung sistem lelang ini telah membatasi anggota masyarakat untuk mengakses sumberdaya tersebut, karena hanya anggota masyarakat yang memiliki kemampuan secara finansial saja yang dapat melakukan usaha penangkapan ikan. Untuk itu, bagi nelayan yang ingin melakukan penangkapan ikan pada wilayah tersebut harus mendapatkan ijin terlebih dahulu dari pengemin selaku pemilik hak usaha penangkapan ikan. Biasanya nelayan membayar sewa kepada pengemin agar dapat melakukan penangkapan ikan. Kondisi tersebut menyebabkan terjadinya hubungan kerja antara pengemin dan nelayan, dimana setiap status memiliki peran masingmasing.

Sejauh ini informasi mengenai nelayan di perairan umum daratan jauh lebih sedikit jika dibandingkan dengan informasi nelayan diperairan laut. Informasi yang ada lebih banyak mengungkapkan tentang bio-ekologisnya saja, sedangkan informasi terkait pola hubungan kerja nelayan di perairan umum daratan belum banyak diungkap, sehingga berdasarkan hal tersebut penelitian ini bertujuan untuk mengkaji pola hubungan kerja yang terjadi dalam kegiatan aktifitas penangkapan ikan di sungai dan rawa banjiran yaitu pola hubungan kerja antar nelayan, nelayan dengan pengemin dan hubungan kerja antara nelayan dengan pedagang pengumpul.

\section{METODOLOGI}

\section{Lokasi dan Waktu Penelitian}

Penelitian ini dilakukan di Desa Berkat, Kecamatan Sirah Pulau Padang, Kabupaten Ogan Komering Ilir, Sumatera Selatan. Kabupaten Ogan Komering Ilir merupakan daerah di Sumatera Selatan yang memiliki 65 persen wilayahnya berupa rawa, payau, lebak dan sungai (Nasution, 2008). Lokasi ini merupakan salah satu lokasi penelitian Panelkanas (Panel Kelautan dan Perikanan Nasional) yang dilakukan oleh Balai Besar Penelitian Sosial Ekonomi Kelautan dan Perikanan. Kegiatan penelitian dilaksanakan pada bulan Mei dan Agustus 2012.

\section{Jenis dan Sumber Data}

Data yang dipergunakan terutama dari data primer yang dikumpulkan dari hasil wawancara mendalam dengan informan kunci. Informan ditentukan dengan menggunakan teknik purposive sampling dengan pertimbangan untuk memenuhi kebutuhan data yang diinginkan, yaitu dengan pemangku kepentingan yang terkait. Pertimbangan lain adalah kemudahan dalam melakukan wawancara dan kesediaan responden dalam 
memberikan informasi yang dibutuhkan dalam kegiatan penelitian. Informan kunci yang dipilih yaitu sebanyak 11 (sebelas) orang, terdiri dari 2 (dua) orang dari Dinas Kelautan dan Perikanan Kabupaten OKI, 2 (dua) orang pengemin (pemenang lelang), 2 (dua) orang pedagang ikan dan 5 (lima) orang nelayan. Data sekunder diperoleh melalui studi pustaka, serta informasi dari instansi-instansi terkait baik pemerintah dan swasta.

\section{Metode Pengumpulan dan Analisis Data}

Untuk mendapatkan pemahaman secara mendalam mengenai pola hubungan kerja dikalangan nelayan pada sungai dan rawa banjiran di Desa Berkat, maka digunakan jenis penelitian kualitatif deskriptif. Adapun yang dimaksud sebagai penelitian kualitatif ialah suatu metode penelitian yang bertujuan untuk menjelaskan fenomena dengan sedalam-dalamnya melalui pengumpulan data sedalam-dalamnya. Penelitian kualitatif tidak mengutamakan besarnya populasi atau sampling, bahkan populasi atau sampel yang diambil sangat terbatas. Jika data sudah mendalam dan menjelaskan fenomena yang diteliti, maka tidak perlu mencari sampling lainnya (Krisyantono, 2006). Pendekatan studi kasus digunakan dalam penelitian ini dengan tujuan untuk menjelaskan suatu fenomena yang dialami (Denzin, 2001), dalam hal ini yaitu fenomena yang dialami oleh nelayan sungai dan rawa banjiran di Desa Berkat yang dilihat dari pola hubungan kerjanya.

Data primer dikumpulkan melalui wawancara mendalam dengan informan secara individual dengan menggunakan daftar pertanyaan terstruktur. Informan ditentukan dengan menggunakan teknik purposive sampling. Mengacu pada Singarimbun dan Effendi (1989), Jumlah informan dalam penelitian studi kasus ini didasarkan pada syarat kecukupan informasi menurut justifikasi peneliti. Data primer dan sekunder yang dikumpulkan kemudian dianalisis dengan menggunakan metode analisis data secara kualitatif melalui tiga proses yaitu reduksi data, penyajian data dan penarikan kesimpulan (Nazir, 2005).

\section{KEADAAN UMUM PERIKANAN TANGKAP}

Kabupaten Ogan Komering Ilir (OKI) terletak di bagian Timur Propinsi Sumatera Selatan antara $104^{\circ} 20^{\prime}$ dan $106^{\circ} 00^{\prime}$ Bujur Timur dan $2^{\circ} 30^{\prime}$ sampai $4^{\circ} 15$ ' Lintang Selatan, dengan ketinggian rata-rata 10 meter diatas permukaan laut. Secara administrasi berbatasan dengan : Kabupaten Banyuasin, Kabupaten Ogan Ilir dan Kota Palembang di sebelah Utara; Kabupaten Ogan Komering Ulu Timur dan Propinsi Lampung di sebelah Selatan; Kabupaten Ogan Ilir dan Kabupaten OKU Timur di sebelah Barat, dan Selat Bangka dan Laut Jawa di sebelah Timur. Kabupaten OKI memiliki wilayah perairan yang sangat besar baik laut maupun perairan pedalaman (umum) sehingga menyimpan potensi yang besar dalam sektor kelautan dan perikanan baik perikanan tangkap maupun budidaya.

Perikanan tangkap mempunyai potensi sumberdaya ikan dengan potensi lestari 45.121,82 ton/tahun. Berdasarkan jumlah tangkap yang dibolehkan (JTB) adalah 36.097,46 ton/tahun, sementara produksi pada tahun 2011 sebesar $32.517,280$ ton/tahun. Produksi ikan perairan umum menurut jenis tahun 2011 dapat dilihat pada Tabel 1.

Kabupaten OKI mempunyai luas wilayah yang mencapai $19.023,47 \mathrm{~km}^{2}$ dan $75 \%$ terdiri dari rawa/perairan ditambah dengan aliran sungai menjadikan Kabupaten OKI mempunyai potensi perikanan yang besar sehingga sektor perikanan menjadi salah satu penyumbang Pendapatan Asli Daerah (PAD). Sebagai wilayah yang mempunyai perairan dengan tipe sungai dan rawa banjiran, di daerah aliran sungai banyak terdapat lebak yang mana pasang surut airnya dipengaruhi oleh musim. Menurut Welcomme (1985) dalam Nasution (2008) menyatakan perairan tipe sungai dan rawa banjiran mempunyai ciri khas, dimana fluktuasi air yang sangat berbeda antara musim penghujan dan musim kemarau. Pada musim penghujan air sungai meluap hingga menggenangi sebagian besar arealnya terkecuali bagian tanah yang tinggi, sebaliknya pada musim kemarau air sungai menjadi surut dan sebagian besar arealnya kering kecuali bagian yang dalam meliputi utama dan lebung. Lebak lebung dan sungai ini mempunyai produktivitas sumberdaya perikanan lebih tinggi daripada perairan lainnya sehingga dijadikan objek lelang oleh Pemerintah Daerah Kabupaten OKI (Nasution, 2008).

Guna membina dan mengembangkan potensi lebak lebung, Pemerintah Kabupaten dan Dewan Perwakilan Rakyat Daerah (DPRD) OKI mengeluarkan Peraturan Daerah (Perda) Nomor 30 tahun 2002 dan Perda Nomor 16 tahun 2003, tentang Lelang Lebak Lebung. Perda ini mengatur sistem penggunaan dan lelang objek lebak dan lebung yang tersebar di sejumlah kecamatan, 
baik yang ukuran kecil, sedang maupun besar. Selanjutnya melalui keputusan Bupati Nomor 452/ KEP/DKP/2007 tentang penetapan objek Lelang Lebak Lebung (L3) tahun 2007 sebesar 30 persen dari total objek lelang yang ada, sedangkan sisanya pengelolaannya diserahkan kepada masyarakat.

Hasil dari Lelang Lebak Lebung (L3) menyumbang besaran uang yang cukup besar ke kas pemerintahan daerah dan pada tahun 2011 total penerimaan daerah dari L3 mengalami peningkatan. PAD dari L3 pada tahun 2010 sebesar Rp 3.5999.325 dan di tahun 2011 meningkat menjadi Rp 5.997.020.000. Besarnya potensi potensi perikanan yang terdapat di Kabupaten OKI membutuhkan pengelolaan dan pemanfaatan yang tepat untuk memberikan keuntungan yang maksimal bagi masyarakat dan pemerintah daerah namun tetap memperhatikan kelestarian sumber daya perikanan.

\section{KARAKTERISTIK NELAYAN PERAIRAN UMUM DARATAN (PUD)}

Berdasarkan statusnya, nelayan PUD di Desa Berkat dapat dibagi menjadi dua, yaitu nelayan pemilik dan nelayan sewa. Nelayan pemilik adalah nelayan yang memiliki hak usaha penangkapan ikan pada wilayah tertentu atau lebih dikenal dengan istilah pengemin (pemenang lelang). Nelayan sewa adalah nelayan yang membayar sewa kepada nelayan pemilik agar dapat melakukan usaha penangkapan di wilayahnya. Tidak semua nelayan pemilik atau pengemin melakukan aktifitas usaha penangkapan ikan pada wilayah lelangnya, namun aktifitas usahanya lebih banyak dilakukan di darat. Hal ini berbeda dengan apa yang dilakukan oleh nelayan sewa, dimana aktifitas penangkapan ikan dilakukan setiap hari sebagai sumber mata pencaharian utama. Pengemin biasanya baru melakukan aktifitas penangkapan pada saat kondisi air surut terendah

Pengemin atau pemenang lelang yang ada di Desa Berkat sebagian besar bukanlah dari kalangan nelayan namun dari kalangan masyarakat pemilik modal atau pedagang. Hal ini seperti yang diungkapkan oleh Nasution (2008), bahwa pengemin sebagai pemegang akses hak penangkapan ikan pada masa pemerintahan kabupaten (setelah tahun 1982) lebih banyak oleh masyarakat pedagang (pemilik modal) dan berbeda kondisinya pada saat masa pemerintahan marga (sebelum tahun 1982) dimana lebih banyak oleh masyarakat nelayan. Hal senada juga disampaikan Zain (1982) dalam

Tabel 1.Produksi Ikan Perairan Umum Menurut Jenis Ikan di Kabupaten OKI Tahun 2011. Table 1. Fish Production in Inland Waters Based on Type of Fish in OKI District, Year 2011.

\begin{tabular}{clr} 
No & \multicolumn{1}{c}{ Jenis Ikan/ Type of Fish } & $\begin{array}{r}\text { Produksi (Ton) / } \\
\text { Production (Tonnes) }\end{array}$ \\
\hline 1 & Jelawat/Mud Barb & 7,134 \\
2 & Lampam/Tinfoil Barb & 949,169 \\
3 & Patin/Pangasius sp & 343,837 \\
4 & Tapa/Catfish & 29,349 \\
5 & Baung/ Asian Retail Catfish & 465,922 \\
6 & Lais/Catfish & 438,509 \\
7 & Gabus/Snakehead & 937,654 \\
8 & Lele/catfish & $1,682,905$ \\
9 & Toman/giant snakehead & 336,092 \\
10 & Sepat Siam/Snakeskin gourami & $1,274,255$ \\
11 & Tambakan/Kissing gourami & 578,831 \\
12 & Belida/Featherbacks & 12,840 \\
13 & Betutu/Marble goby & 11,143 \\
14 & Ikan lainnya/ Other fish & $3,643,715$ \\
15 & Udang Galah/Giants freshwater prawns & 337,519 \\
16 & Udang lainnya /Other shrimp & 324,373 \\
17 & Kodok/Frog & 304,602 \\
18 & Kura-kura/Turtle & 5,231 \\
\hline & Jumlah/Total & $\mathbf{1 1 , 6 8 3 , 0 8 0}$ \\
\hline
\end{tabular}

Sumber : Dinas KP Kabupaten OKI, 2012/Source : Marine and Fisheries Agency in OKI District, 2012 
Nasution (2008) bahwa warga yang bukan nelayan diizinkan ikut serta dalam pelelangan. Berdasarkan aktifitas penangkapan ikan yang dilakukan, nelayan PUD di Desa Berkat dapat dikategorikan sebagai nelayan musiman, karena kegiatan penangkapan ikan yang dilakukan tidak sepanjang tahun, yaitu hanya pada saat kondisi air tinggi, sedangkan pada saat kondisi air surut, biasanya para nelayan beralif profesi sebagai petani yang memanfaatkan lahan yang sudah tidak tergenang air untuk menanam padi.

Secara umum nelayan di Kabupaten OKI adalah nelayan tradisional dan hal ini ditandai dengan penggunaan sarana penangkapan yang sederhana dan usaha penangkapan yang bersakala kecil misalnya dengan menggunakan perahu dayung, layar dan motor tempel. Keadaan seperti tersebut diatas juga berlaku untuk nelayan di Desa Berkat dimana sebagian besar nelayan melakukan usaha penangkapan dengan menggunakan perahu dayung, teknologi yang sederhana dan dilakukan oleh perseorangan.

Sarana penangkapan nelayan di Desa Berkat berupa perahu tanpa motor yang berukuran $5 \mathrm{~m} \times 1 \mathrm{~m} \times 1 \mathrm{~m}$ dengan status kepemilikan sebagai nelayan pemilik dan operasi penangkapan satu hari (one day fishing). Selain perahu sarana lain yang digunakan dalam usaha penangkapan adalah alat tangkap dan pada umunya alat tangkap yang digunakan adalah jaring, temilar, pancing (tajur), bubu, bubu belut, serkap. Usaha penangkapan ikan oleh nelayan selama satu tahun terdiri dari 2 musim yaitu musim puncak dan musim paceklik dan dilakukan pada saat memasuki musim penghujan. Kegiatan menangkap ikan dalam istilah setempat disebut dengan "bekarang", dan di tahun 2012 kegiatan bekarang efektif berlangsung selama 5 bulan yaitu bulan Januari - Mei. Pada bulan Januari - Maret dikategorikan dalam musim paceklik yaitu ketika air tinggi di area sungi dan lebak lebung dengan frekuensi penangkapan antara 10 - 15 hari/ bulan. Berbeda halnya pada musim puncak yaitu menjelang air surut (menjelang musim kemarau) di Bulan Maret - Mei, terjadi peningkatan jumlah hari penangkapan menjadi 20-25 hari/bulan.

\section{POLA HUBUNGAN KERJA NELAYAN PERAIRAN UMUM DARATAN}

Pola hubungan kerja komunitas nelayan di Desa Berkat, menjadikan kepercayaan sebagai dasar penting dalam kehidupan sosial. Nelayannelayan tersbut merupakan anggota dalam satu kelompok. Kebersamaan dan kepercayaan dominan dalam kehidupan sehari-hari nelayan di Desa Berkat sehingga menjadi karakter sosial budaya masyarakat setempat. Setiap bentuk kegiatan sosial yang dilakukan merupakan hasil rembukan atau musyawarah/kesepakatan bersama. Seperti yang diungkapkan oleh Putnam (1993), bahwa rasa percaya, norma timbal-balik dan jaringan sosial merupakan modal sosial yang memungkinkan para partisipan (masyarakat) bertindak bersama secara lebih efektif untuk mencapai tujuan bersama.

Dalam struktur nelayan perairan umum daratan, ada dua pihak yang berperan pada posisi struktur atas yaitu pengemin atau pemenang lelang dan pedagang pengumpul. Pada kasus di Desa Berkat ada juga pengemin yang berstatus sebagai pedagang pengumpul. Pengemin merupakan nelayan dengan status sosial yang lebih tinggi dari tipe nelayan lainnya, oleh karena itu kekuasaan pengemin di Desa Berkat sangat dominan terhadap nelayan lainya yang bekerja atau menyewa sebagian perairan pada pengemin untuk menangkap ikan. Pengemin bersedia memberikan hak penangkapan ikan di wilayah perairan yang dibelinya kepada nelayan. Keterikatan pengemin dengan nelayan sewa yaitu karena adanya sebuah pinjaman uang sebesar nilai sewa objek lelang selama satu tahun dari nelayan sewa kepada pengemin dengan mekanisme pembayarannya secara hutang atau akan dibayarkan oleh nelayan sewa kepada pengemin setelah satu tahun berikutnya. Persyaratan yang diberikan yaitu nelayan sewa harus menjual ikan hasil tangkapannya kepada pengemin dengan harga yang ditentukan oleh pengemin. Harga yang ditentukan biasanya lebih rendah dari harga pasar atau jika nelayan tersebut menjualnya langsung ke pasar atau konsumen. Jika harga ikan gabus di pasar senilai Rp. 35.000/ $\mathrm{kg}$, maka untuk di pengemin dapat dihargai hanya Rp. 28.000/kg. Pada Gambar 1 dapat diketahui bahwa nelayan yang menjual ikannya di pengemin akan memperoleh uang yang lebih sedikit jika nelayan menjual ikan di pasar. Hal ini karena harga beli ditingkat pengemin lebih rendah dibandingkan di pasar.

Hubungan patron klien pun terjadi antara pedagang pengumpul (bukan pengemin) dengan nelayan. Keterikatan antara patron (pedagang pengumpul) dengan klien (nelayan) terjadi akibat adanya pinjaman modal nelayan kepada pedagang pengumpul dalam bentuk umpan (kodok/bancet) yang digunakan oleh nelayan sebagai umpan menangkap ikan gabus atau toman. 


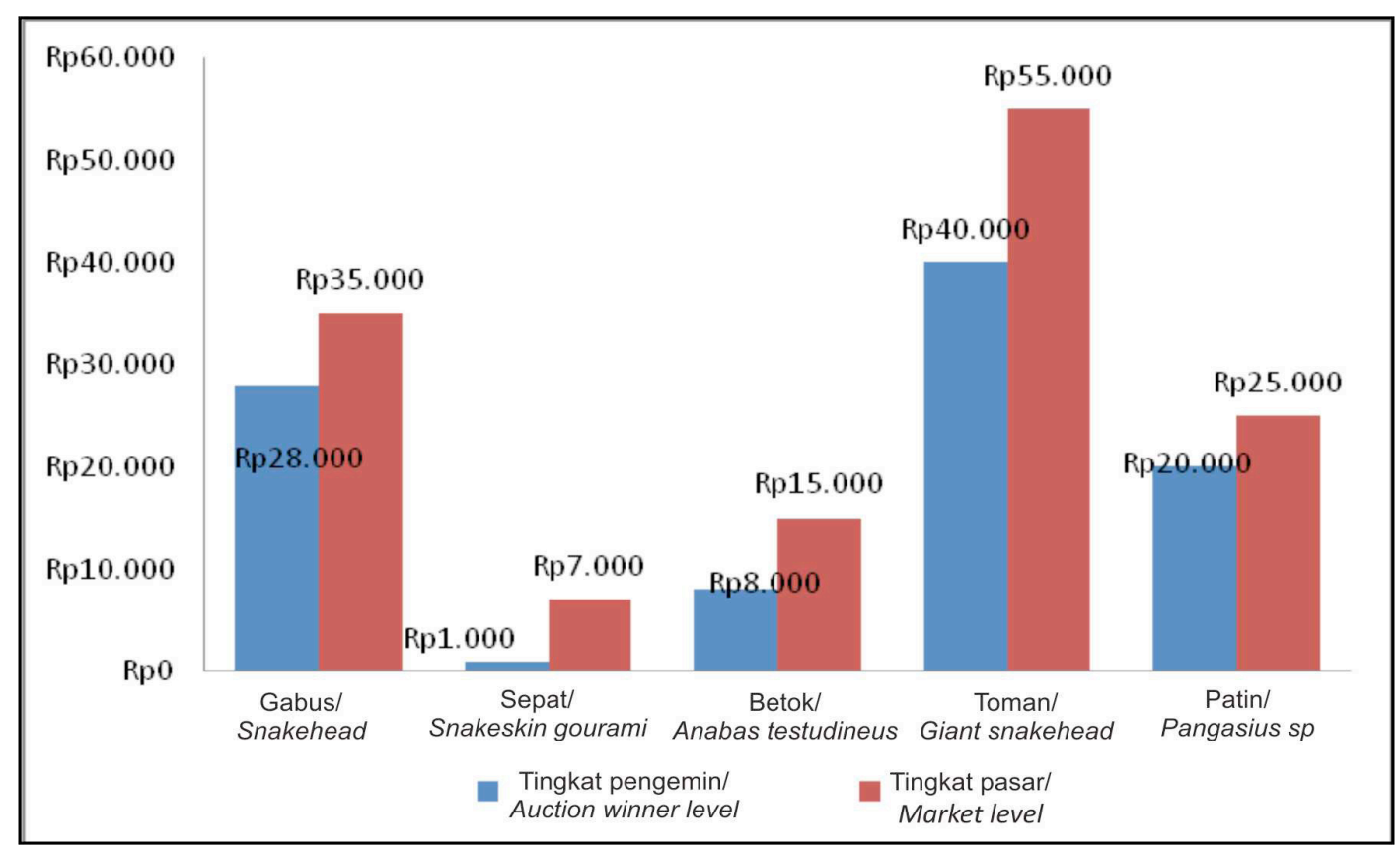

Gambar 1. Variasi Harga Jual Ikan Hasil Tangkapan Nelayan Pada Tingkat Pengemin dan Pasar, Juli 2012.

Figure 1. Variation on Fish Selling Prices on Auction Winner and Market Level, July 2012.

Ikan gabus dan toman merupakan salah satu ikan target utama karena memiliki nilai jual yang lebih tinggi dibanding ikan lainnya. Bagi nelayan yang meminjam uang dalam bentuk umpan kepada pedagang pengumpul tentu saja ikan hasil tangkapan harus dijual kepada pedagang tersebut. Namun untuk harga ikan yang dijual pada umumnya tidak beda atau tidak lebih rendah dari harga di pasar karena pinjaman utang umpan tersebut langsung di potong dari hasil penjualan ikannya atau jika tidak cukup dibebankan kepada penjualan berikutnya.

Hubungan patron klien pun terjadi antara pedagang pengumpul (bukan pengemin) dengan nelayan. Keterikatan antara patron (pedagang pengumpul) dengan klien (nelayan) terjadi akibat adanya pinjaman modal nelayan kepada pedagang pengumpul dalam bentuk umpan (kodok/bancet) yang digunakan oleh nelayan sebagai umpan menangkap ikan gabus atau toman. Ikan gabus dan toman merupakan salah satu ikan target utama karena memiliki nilai jual yang lebih tinggi dibanding ikan lainnya. Bagi nelayan yang meminjam uang dalam bentuk umpan kepada pedagang pengumpul tentu saja ikan hasil tangkapan harus dijual kepada pedagang tersebut. Namun untuk harga ikan yang dijual pada umumnya tidak beda atau tidak lebih rendah dari harga di pasar karena pinjaman utang umpan tersebut langsung di potong dari hasil penjualan ikannya atau jika tidak cukup dibebankan kepada penjualan berikutnya.

Untuk pengemin yang berstatus sebagai pedagang pengumpul di Desa Berkat, tidak semuanya memberikan pinjaman utang umpan kepada nelayan, kebanyakan keterikatan antara nelayan dengan pengemin di Desa Berkat hanya sebatas pinjaman terkait sewa hak penangkapan dalam objek lelang. Untuk nelayan di Desa Berkat terkait status sewa hak penangkapan terdapat dua macam, yaitu nelayan yang membayar sewa secara tunai di awal musim penangkapan dan nelayan yang membayar sewa di akhir musim (hutang). Maka untuk nelayan yang membayar tunai di awal musim penangkapan dapat secara bebas menjual ikan tidak harus kepada si pengemin. Nelayan tersebut memiliki hak untuk memilih pedagang mana yang dapat membeli ikannya dengan pertimbangan harga yang ditawarkan lebih tinggi. Namun jika nelayan tersebut juga memiliki pinjaman dalam bentuk umpan kepada pedagang pengumpul maka secara otomatis dia harus menjual ikan hasil tangkapannya kepada pedagang tersebut. 


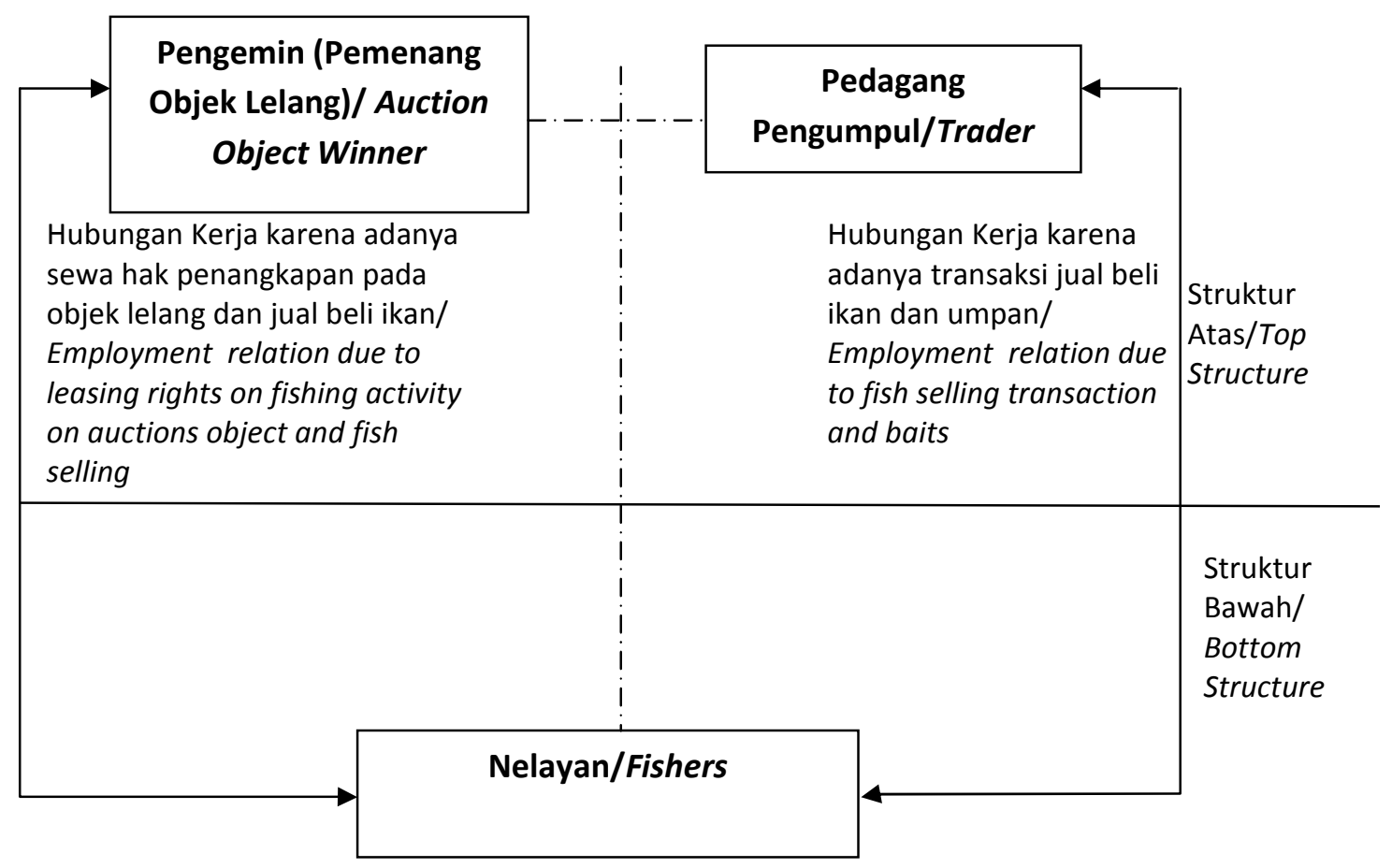

Gambar 2. Struktur dan Hubungan Kerja Nelayan di Desa Berkat, Kabupaten OKI.
Figure 2. Structure and Fishers Working Relation in Berkat Village, OKI District.

Dalam kenyataannya pola hubungan kerja antara patron dan kliennya tidak terjadi secara ketat. Khususnya terkait dengan keterikatan antara pengemin/pedagang pengumpul dengan nelayan karena adanya pinjaman modal. Jika nelayan tidak dapat membayar hutang dengan tepat sesuai dengan perjanjian maka pengemin/pedagang pengumpul dapat memberikan keringanan dengan memberikan perpanjangan waktu pembayaran. Namun dalam hal ini yang dibutuhkan adalah kejujuran, misalkan si pengemin/pedagang pengumpul mengetahui bahwa nelayan (kliennya) menjual ikan kepada pengumpul lain karena harga yang lebih tinggi maka pengemin/pedagang pengumpul tidak akan memberikan kesempatan lagi kepada nelayan tersebut untuk menyewa objek lelangnya atau meminjam uang kepadanya lagi. Sejauh ini, hubungan kerja yang dirasakan oleh nelayan dengan pengemin/pedagang pengumpul dirasakan saling menguntungkan baik dari pihak nelayan maupun pengemin/pedagang pengumpul. Permasalahan yang lebih sering muncul bukanlah akibat pola hubungan kerja yang terjadi namun lebih kearah hasil tangkapan ikan yang dirasakan terus menurun dari tahun ke tahun baik dari jumlah yang ditangkap maupun jenis ikan yang tertangkap. Pada Tabel 2 berikut dapat dilihat pola hubungan kerja nelayan perairan umum daratan di Desa Berkat.

Modal sosial yang dimiliki oleh komunitas nelayan di Desa Berkat dapat dilihat sebagai aksi bersama untuk mengelola sumber daya ikan diwilayahnya melalui aturan dan sanksi. Ostrom et al., (1994) menyatakan bahwa karakteristik sumber daya memiliki 2 karakteristik utama. Pertama, memiliki sifat substractibility atau rivalness didalam pemanfaatannya, dalam arti setiap konsumsi atau pemanenan seseorang atas sumber daya akan mengurangi kemampuan atau jatah orang lain dalam memanfaatkan sumberdaya tersebut. Kedua, adanya biaya (cost) yang harus dikeluarkan untuk membatasi akses sumber daya pada pihak-pihak lain untuk menjadi pemanfaat (beneficiaries). Dalam hal ini, pengemin sebagai pemenang lelang merupakan pihak yang mengeluarkan biaya sehingga membatasi pihakpihak lain untuk mengeksploitasi sumber daya ikan pada badan sungai yang dilelang. Namun pada kenyataannya pengemin tetap dapat memberikan peluang untuk pihak lain mengeksploitasi ikan yang ada pada objek lelang. 
Tabel 2. Pola Hubungan Kerja Nelayan Perairan Umum Daratan di Desa Berkat, Kabupaten OKI, Tahun 2012.

Table 2. Working Relation Pattern of Inland Water Fishers in Berkat Village, OKI District, Year 2012.

\begin{tabular}{|c|c|c|}
\hline No & $\begin{array}{l}\text { Pola Hubungan } \\
\text { Kerja/ Working } \\
\text { RelationPattern }\end{array}$ & Bentuk Hubungan/ Relation Form \\
\hline 1 & $\begin{array}{l}\text { Pola } 1 \text { (Patron } \\
\text { Klien)/ Pattern } 1\end{array}$ & $\begin{array}{l}\text { a. Struktur atas : Pengemin sekaligus pedagang pengumpul./ } \\
\text { Top Structure : Auction Winner also as trader } \\
\text { b. Modal : Hutang atas pembayaran sewa objek lelang dari } \\
\text { nelayan kepada pengemin./ Capital : Liabilities for lease auction } \\
\text { object from fishers to auction winner } \\
\text { c. Keterikatan : Menjual hasil tangkapan ikan kepada pengemin } \\
\text { dengan harga yang ditentukan oleh pengemin (biasanya lebih } \\
\text { rendah)/ Entanglement: Selling fish caught to auction winner at } \\
\text { prices determined by auction winner (usually lower) } \\
\text { a. Struktur atas : Pedagang pengumpul/ Top structure : Trader } \\
\text { b. Modal : Hutang atas pembelian umpan untuk menangkap } \\
\text { ikan./ Capital : Liabilities on fish baits } \\
\text { c. Keterikatan : Menjual hasil tangkapan kepada pedagang } \\
\text { pengumpul dengan harga yang sama di pasar. Pembayaran } \\
\text { hutang dilakukan dari pemotongan hasil penjualan ikan./ } \\
\text { Entanglement : Selling fish caught to traders with the same } \\
\text { market price. Loan repayment deductions made from fish } \\
\text { selling. }\end{array}$ \\
\hline 2 & $\begin{array}{l}\text { Pola } 2 \text { ( Non Patron } \\
\text { Klien)/ Pattern } 2\end{array}$ & $\begin{array}{l}\text { - Nelayan yang membayar sewa lelang di awal musim } \\
\text { penangkapan dan tidak meminjam uang untuk membeli umpan } \\
\text { kepada pedagang pengumpul./ Fishers who pay auction rent in } \\
\text { the early fishing season and not borrow money to buy baits to } \\
\text { traders } \\
\text { - Bebas menjual hasil tangkapan ikan kepada siapa saja sesuai } \\
\text { dengan keinginan./ Free selling catches to anyone }\end{array}$ \\
\hline
\end{tabular}

Sumber : Data Primer Diolah, 2012/Source : Processed Primary Data, 2012

Untuk menjaga kelestarian sumber daya ikan atau keberlanjutan produksi ikan pada objek lelang maka pengemin memberlakukan peraturan terkait penggunaan alat tangkap yang dapat digunakan. Pada objek lelang di Desa Berkat, pengemin melarang penggunaan alat tangkap bubu belut dan jaring ikan yang memiliki mata jaring kurang dari 4 inchi. Menyangkut ciri sumber daya (common pool resources) menurut Ostrom et al. (1994), kehadiran free rider menimbulkan permasalahan karena pihak ini adalah pihak yang mendapatkan manfaat dari sumber daya namun tidak memberikan kontribusi pada biaya-biaya yang harus dikeluarkan untuk menyediakan, memelihara dan mengatur pemanfaatan sumber daya. Dalam hal ini yaitu adanya nelayan yang tidak memiliki hak sewa penangkapan pada objek lelang yang menangkap pada objek lelang tersebut dan juga nelayan yang menggunakan alat tangkap yang bersifat destructive. Pemanfaatan yang berlebihan (overuse) oleh pengemin sebagai pemegang hak penangkapanpada objek lelang dapat mengancam keberlanjutan sumberdaya ikan pada perairan tersebut.

\section{PENUTUP}

Pola hubungan kerja nelayan perairan umum daratan terdapat dua macam, yaitu yang bersifat patron klien dan non patron klien. Untuk pola hubungan kerja yang bersifat patron klien terdapat dua pihak yang berada pada struktur atas, yaitu pengemin dan pedagang pengumpul. Keterikatan antara pengemin/pedagang pengumpul (patron) dengan nelayan (klien) akibat adanya peminjaman modal dari nelayan kepada pengemin/pedagang 
pengumpul baik dalam bentuk biaya sewa lelang maupun modal untuk membeli umpan (kodok/ bancet). Konsekuensi dari keterikatan ini maka mengharuskan nelayan untuk menjual ikan hasil tangkapannya kepada pengemin/pedagang pengumpul. Hubungan kerja yang dirasakan oleh nelayan dengan pengemin/pedagang pengumpul dirasakan saling menguntungkan baik dari pihak nelayan maupun pengemin/pedagang pengumpul.

Permasalahan yang timbul dalam usaha penangkapan ikan yang dilakukan oleh nelayan perairan umum daratan bukanlah dari pola hubungan kerja yang ada, namun lebih kearah semakin menurunnya hasil tangkapan ikan dari tahun ketahun baik dari segi jumlah maupun jenis ikan yang tertangkap. Oleh karena itu, disarankan dalam pemanfaatan sumber daya ikan di perairan umum daratan perlu diberlakukannya pengelolaan terkait pemanfaatan tersebut. Pengelolaan yang dilakukan dapat berupa : (1) Pembatasan atau pelarangan penggunaan jenis alat tangkap yang dapat merusak keberlanjutan sumber daya ikan seperti setrum, potas maupun alat tangkap yang tingkat selektifitasnya sangat rendah (jaring dengan ukuran mata jaring yang kecil), (2) Pelarangan penangkapan ikan yang masih kecil atau juvenil, hal ini dimaksudkan agar tetap menjaga keberlanjutan jenis ikan tersebut, sehingga ikan ikan kecil tersebut mendapat kesempatan untuk berkembang biak dan (3) Dibentuknya daerah konservasi pada sebagian badan sungai/lebak yang merupakan tempat memijahnya ikan.

\section{DAFTAR PUSTAKA}

Denzin, N. K. 2001. Teori dan Paradigma Penelitian Sosial. Tiara Wacana. Yogyakarta.

Dinas Kelautan dan Perikanan Kabupaten Ogan Komering Ilir. 2012 Laporan Tahunan Dinas Kelautan dan Perikanan Kabupaten OKI. Ogan Komering Ilir.
Koeshendarajana, S., T. Apriliani, M. Firdaus, Z. Nasution, A. Nurfiarini. 2011. Penebaran Ikan Bandeng di Waduk Jatiluhur : Analisis Dampak dan Kebijakan Pengembangan. Jurnal Kebijakan Sosial Ekonomi Kelautan dan Perikanan. Vol 1 (1): 1- 17.

Krisyantono, R. 2006. Teknik Praktis Riset Komunikasi; Disertai Contoh Praktis Riset Media, Public Relations, Advertising, Komunikasi Organisasi, Komunikasi Pemasaran. Kencana. Jakarta.

Mintoro. L, Darmajanti L., dan E. Afrianto, 1993. Keragaan Beberapa Pola Usaha Penangkapan Ikan di Laut Oleh Rakyat Indonesia. Pusat Penelitian Sosial Ekonomi Pertanian. IPB. Bogor.

Mubyarto, 1984. Strategi Pembangunan Pedesaan. Pusat Penelitian Pembangunan Pedesaan dan Kawasan. Universitas Gajah Mada. Yogyakarta.

Nasution, Z. 2008. Perkembangan Ekonomi Masyarakat Nelayan Perairan Umum "Lebak Lebung”. Sodality : Jurnal Transdisiplin Sosiologi, Komunikasi dan Ekologi Manusia. Vol 02 (02): 249-264.

Nazir, M. 2005. Metode Penelitian. Ghalia Indonesia. Bogor.

Ostrom, E,. R Gardner, and J. Walker, 1994. Rules, Games and Common-Pool Resources, University Of Michigan Press. Ann Arbor, MI.

Putnam, R. D. 1993. Making Democracy Work: Civic Traditions in Modern Italy. Princeton University Press. New Jersey.

Salman dan A.H. Taryoto, 1992. Pertukaran Sosial Pada Masyarakat Petambak : Kajian Struktur Sosial Sebuah Desa Kawasan Pertambakan di Sulawesi Selatan. Jurnal Agro Ekonomi II.

Singarimbun, M. dan S. Effendi. 1989. Metode Penelitian Survei. Penerbit LP3ES. Jakarta. 